\title{
Development of Science STS Learning Tools Integrated Local Potential of Kacang Shanghai to Increase Critical Thinking Skills and Technology Literacy: A Literature Review
}

\author{
Zahrotun Nafi' ${ }^{1}{ }^{1, *}$ Insih Wilujeng ${ }^{2,}$ Wilda Muhimmatun Nisa ${ }^{1}$
}

\author{
${ }^{I}$ Master of Natural Science Education, Faculty of Mathematics and Natural Sciences, Universitas Negeri \\ Yogyakarta, Indonesia \\ ${ }^{2}$ Department of Natural Science Education, Faculty of Mathematics and Natural Sciences, Universitas Negeri \\ Yogyakarta, Indonesia \\ *Corresponding author.Email: zahrotunnafiah.2019@student.uny.ac.id
}

\begin{abstract}
Critical thinking skills and technology literacy are still slightly for students. It happens because the learning process has not focused on improving critical thinking skills and technology literacy. Learning has implemented the activities that including indicators of critical thinking skills, however the implementation has not been properly as students do not emphasis on learning meanwhile learning which links technology literacy has not been developed yet. The integrated STS IPA learning device of local potential of kacang shanghai (shanghai bean) can facilitate students to improve critical thinking skills and technology literacy. It raises the problems which are close to students so that they are more interested in taking part of learning.
\end{abstract}

Keywords: STS, Local potential, Critical thinking skills, Technology literacy

\section{INTRODUCTION}

The development of the 2013 curriculum is to be expected to assist students in developing their abilities and skills towards increasingly fierce global competition [1]. The 2013 curriculum applies a student centered learning process [2]. By this curriculum, classroom learning requires students to be active in building their own knowledge. It has an impact on students' abilities to become better than those who learn conventionally (teacher centered) [3]. The learning process that centers of students' activeness affects students' critical thinking skills [4].

Critical thinking skills are a thinking model to enhance structured thinking skills that are functional for problem solving [5]. These are one of the characteristics of learning in the 21 st century [6], so that critical thinking skills are highly important in the learning process. Based on educational regulations, Junior High School students are demanding to have the reasoning ability, processing, and presenting creatively, productively, critically, independently, collaboratively and communicative. Piaget's cognitive development also shows that the age of 11 years and over is classified as a formal operational stage so that junior high school students are able to formulate problem solving related to everyday life [7].

However, the critical thinking skills of junior high school students in Indonesia are still low. It can be seen from the results of TIMSS and PISA, which were followed by Indonesian junior high school students. The result of TIMSS in the field of science in 2011 showed that Indonesian students obtained a score of 406 by an average score of 500 [8]. The result of PISA in the field of science in 2018 showed that Indonesian students obtained a score of 396 by an average score of 489 [9].

The cause of students' lack of critical thinking skills is to learn which is emphasizing critical thinking skills where it has not become the main focus of learning in schools [10]. The learning process has certainly implemented activities to inquire questions, provide solutions, and solve problems that can raise 
students' critical thinking skills. Nevertheless, in practice, there are some students who are not attentive and serious during in the learning process. Those are still numerous students who are inactive even though they experience several difficulties during in the learning process [11].

Critical thinking skills can be expanded through in the learning process at schools [12]. The learning process is able to be student-centered, which refers to the scientific inquiry process with constructivist principles. The STS (science, technology, society) approach is an approach that adopts the theory of constructivism. The approach can also instruct the students to apply science principles which are linked to technology and can be implemented in the society [13]. Learning with the STS approach is able to increase students' critical thinking skills [4].

Additionally, to improve critical thinking skills, the STS approach is as well regarded to the technology literacy. Technology literacy is the ability to utilize, manage, assess, and understand the technology. Technology refers to the relationship between individuals and society, then, the design and problemsolving process, and as an object of assessment [14]. Based on the explanation, technology literacy is predominant to be included in the classroom learning. However, science learning in Indonesia has not implemented learning which links technology literacy.

Furthermore, the learning is student-centered while science learning needs to be carried out contextually which is linked to everyday life [15]. Community or industrial activities that exist in a local area can be used to support learning, i.e., local potential [12]. There are a plenty of regional potentials in Indonesia, including local potentials correlated to the entrepreneurial world (home industry) [16]. Integrated learning of local potential make students to know and take the advantage of local potential in their area as a local cultural heritage [17]. The development and implementation of learning should be centered on the potential, development, necessity and interests of students and their environment, thus, utilizing the surrounding environment as a learning resource [18].

\section{A REVIEW OF THE DEVELOPMENT OF STS IPA LEARNING TOOLS INTEGRATED LOCAL POTENTIAL OF KACANG SHANGHAI TO INCREASE CRITICAL THINKING SKILLS AND TECHNOLOGY LITERACY}

\subsection{STS IPA Learning Tools Integrated Local Potential of Kacang Shanghai}

Learning media are tools and materials which are utilized by teachers to carry out learning [19], [20]. The learning media which are used in the implementation of learning includes syllabus, lesson plan (RPP), teaching materials, student activity sheets (LKS), and assessment instruments [2], [21]-[23]. The syllabus is a reference for preparing of a learning framework (RPP) for each subject in a study material. The lesson plan (RPP) is a face-to-face learning activity for one or more meetings and it contains what will be taught (content) and teaching suggestions [24]. Student activity sheets (LKS) are printed teaching materials in the form of sheets of paper containing material, summaries, and instructions for implementing learning tasks that are able to be finished by students. LKS refers to the basic competencies to be achieved [25].

According to the National Science Teachers Associations (NSTA), STS is learning science and technology in the context of human experience [26]. STS is able to be defined as learning designed using social and technology issues in the student environment as well [27]. STS as an approach integrates science, technology, and society that indicates the relationship of these three aspects [28]. The STS approach has several differences compared to other learning approaches. Their differences are in the connection and application of learning materials, creativity, attitudes, processes, and concepts of knowledge. The STS approach includes problemsolving activities that maintains problems in everyday life. The characteristic of STS learning is to prepare students to be able to use science to predict their own lives and to face the increasingly complex world of the technology [29]. The synthesis of the STS approach steps can be seen in Table 1 and the STS approach steps that will be used in the study can be seen in Table 2 below. 
Table 1. Synthesis of the STS approach steps

\begin{tabular}{|c|c|c|c|c|}
\hline Poedjiaji, 2010 [30] & Zuldafrial, 2012 [31] & Hunaepi, 2014 [32] & $\begin{array}{c}\text { Gathong \& Chamrat, } \\
2019 \text { [28] }\end{array}$ & Synthesis \\
\hline \multirow{2}{*}{$\begin{array}{l}\text { - Initiation / invitation } \\
\text { / exploration / } \\
\text { apperception }\end{array}$} & \multirow[t]{2}{*}{ - Invitation } & \multirow{2}{*}{$\begin{array}{l}\text { - Identify the } \\
\text { problem }\end{array}$} & - Awakening interest & \multirow[t]{2}{*}{ - Invitation } \\
\hline & & & $\begin{array}{l}\text { - Planning for } \\
\text { searching answers }\end{array}$ & \\
\hline $\begin{array}{l}\text { - Concept formation / } \\
\text { development }\end{array}$ & - Exploration & $\begin{array}{l}\text { - Searching for } \\
\text { information }\end{array}$ & $\begin{array}{l}\text { - Finding answers } \\
\text { using empirical } \\
\text { evidence }\end{array}$ & - Exploration \\
\hline $\begin{array}{l}\text { - Concept application } \\
\text { in life }\end{array}$ & \multirow{2}{*}{$\begin{array}{l}\text { - Propose } \\
\text { explanations and } \\
\text { solutions }\end{array}$} & \multirow[t]{3}{*}{$\begin{array}{l}\text { - Looking for a } \\
\text { solution }\end{array}$} & - Reflection feedback & \multirow[t]{2}{*}{$\begin{array}{l}\text { Explanations } \\
\text { and Solutions }\end{array}$} \\
\hline - Conceptualization & & & $\begin{array}{l}\text { - Applying authentic } \\
\text { action and } \\
\text { publishing results }\end{array}$ & \\
\hline - Assessment & - Take action & & - Evaluation & $\begin{array}{l}\text { - Determination } \\
\text { of Action }\end{array}$ \\
\hline
\end{tabular}

Table 2. Steps for the STS approach that will be used in the study

\begin{tabular}{|c|c|c|}
\hline No. & Step & iption \\
\hline 1 & Invitation & $\begin{array}{l}\text { - The teacher invites the students to recollect or display the events in the society through } \\
\text { the print and electronic media related to the topic. } \\
\text { - Students formulate the problems by relating the topics discussed. The teacher is able } \\
\text { to buckle as a facilitator at this stage and straighten it in order to not get out of topic. } \\
\text { - Students formulate the hypotheses from the problem formulations that have been } \\
\text { made. }\end{array}$ \\
\hline 2 & Exploration & $\begin{array}{l}\text { - Students seek or tests the hypotheses which have been created by looking for data } \\
\text { from the various sources of the information (books, newspapers, magazines, } \\
\text { environment, sources, related agencies, or conducting experiments). } \\
\text { - Students analyze data which have been obtained through brainstorming, } \\
\text { experimenting, observing phenomena, designing models or works, and discussing } \\
\text { problem solving. } \\
\text { - Activities carried out by students can refer to the LKS. }\end{array}$ \\
\hline 3 & $\begin{array}{l}\text { Explanations and } \\
\text { Solutions }\end{array}$ & $\begin{array}{l}\text { - Students are invited to communicate the ideas from analyzing the information } \\
\text { obtained, then, compile an explanatory model, review and discuss the solutions } \\
\text { obtained, and determine several solutions. } \\
\text { - The teacher guides students to combine the resulting concepts with the concepts } \\
\text { adopted by science experts. }\end{array}$ \\
\hline 4 & $\begin{array}{l}\text { Determination of } \\
\text { Action }\end{array}$ & $\begin{array}{l}\text { - Students are invited to make a decision by considering the mastery of science concepts } \\
\text { and skills possessed and in the position of students as individuals or society. }\end{array}$ \\
\hline
\end{tabular}

The integration of local potential in learning needs to be directed at achieving completely in the student learning outcomes so that it can be applied in everyday life [33]. The teachers bring out the local potential in 
every lesson either through several examples, strengthening material, analyzing problems, and solving them [34]. They are able to analyze the local potential around the school to be used as a learning resource [35]. There are various the local potentials around the school that can be integrated into science learning [36]. The integration of local potential is to be done in the preparation of the syllabus, lesson plans, and ICT-based learning [37].

The local potential of kacang shanghai is one of the local potentials in Ngunut, Tulungagung, East Java. Kacang shanghai are a typical Tulungagung snack that is crunchy and savory. Kacang shanghai are made from selected peanuts wrapped in a dough of seasoned flour. The location of the kacang shanghai company is extremely close to the junior high school in Ngunut. Depend on the observations, kacang shanghai company is excessively unclosed to being used as a place of the study for students, i.e., accept a plenty of schools, although the schools are close to the location of the kacang shanghai company that has never committed directly to study. The process of making kacang shanghai can be related to the science materials at the junior high school level. Thus, one of the lessons can be related to the temperature and heat materials. The integration of local potential of kacang shanghai with temperature and heat material is able to be shown in Table 3 below.

Table 3. Integration of local potential of kacang shanghai with material of temperature and heat

\begin{tabular}{|c|l|l|}
\hline No. & \multicolumn{1}{|c|}{ Sub Topic } & \multicolumn{1}{c|}{ Local Potential of Kacang Shanghai } \\
\hline 1 & Temperature and expansion & $\begin{array}{l}\text { An expansion that occurs in tools and materials for making } \\
\text { kacang shanghai. }\end{array}$ \\
\hline 2 & The change of the temperature and the form & $\begin{array}{l}\text { Changing that occurs during the process of making kacang } \\
\text { shanghai. }\end{array}$ \\
\hline 3 & Heat transfer & $\begin{array}{l}\text { Transfer of heat during the process of making kacang } \\
\text { shanghai. }\end{array}$ \\
\hline
\end{tabular}

The temperature and expansion of the local potency of kacang shanghai can be learnt in the tools and materials for making kacang shanghai. An example of temperature is the right temperature to use in making kacang shanghai. Meanwhile, the expansion is able to be learned from the different sizes of the devices that are used in making kacang shanghai and the different sizes of the kacang shanghai after frying. Changing in the temperature and the shape in the local potency of kacang shanghai is to be studied in the process of making kacang shanghai. The change of the temperature of the kacang shanghai is to occur before and after frying, thus, in the devices and the ingredients that are used during the making of kacang shanghai. The form's changing that occurs, including the change of shape, i.e., from soft to hard after being fried, to become thicker. The transfer of heat to the local potency of kacang shanghai can be learnt in the process of making kacang shanghai such as transferring of heat from the fire and oil to the tools used for frying. In addition, heat transfer can be found in the cooling process of kacang shanghai before and the process of packaging as well.

Based on the description above, it can be concluded that the STS IPA learning tools integrated local potential of kacang shanghai is a science learning plan that uses the STS approach and is integrated with the local potential of kacang shanghai. The learning tools including syllabus, lesson plans, and worksheets.

\subsection{Critical Thinking Skills}

Critical thinking is a process of thinking that makes sense and reflective, focusing on making decisions about what to believe or do [38], [39]. [40] explains that the critical thinking as a thought process to prove and interpret something, and solve problems. Moreover, critical thinking is a part of higher order thinking (HOTS). Critical thinking skills are the intellectually disciplined process of actively and selfregulation that are directed at solving the right problem [11].

Critical thinking skills are used to solve concepts or ideas, to separate, to select, to recognize, to study, and to develop towards better goals [41]. Critical thinking skills make the decisions after analyzing, synthesizing, and concluding the information obtained [11]. The synthesis of critical thinking skills can be seen in Table 4 and indicators of critical thinking skills that will be used in the study can be seen in Table 5 below. 
Table 4. Synthesis of critical thinking skills' indicators

\begin{tabular}{|c|c|c|c|}
\hline Ennis, 2011 [39] & Facione, 2011 [40] & Tawil \& Liliasari, 2013 [42] & Synthesis \\
\hline $\begin{array}{l}\text { - Formulate questions } \\
\text { - Analyze arguments } \\
\text { - Ask and answer questions }\end{array}$ & $\begin{array}{l}\text { - Examine ideas } \\
\text { - Identify arguments } \\
\text { - Identify reasons and } \\
\text { claims }\end{array}$ & $\begin{array}{l}\text { - Identify/ formulate } \\
\text { questions/ problems } \\
\text { - Answer the question }\end{array}$ & - Identify the problem \\
\hline $\begin{array}{l}\text { - Define terms } \\
\text { - Define assumptions }\end{array}$ & $\begin{array}{l}\text { - Categorize } \\
\text { - Decode significance } \\
\text { - Clarify meaning }\end{array}$ & $\begin{array}{l}\text { - Define a defined strategy } \\
\text { - Determine the definition } \\
\text { of the subject matter }\end{array}$ & - Categorizing \\
\hline - Determine action & $\begin{array}{l}\text { - Self-monitor } \\
\text { - Self-correct }\end{array}$ & $\begin{array}{l}\text { - Applying the principle/ } \\
\text { formula } \\
\text { - Consider alternatives } \\
\text { - Using a logical strategy }\end{array}$ & $\begin{array}{l}\text { - Conduct an } \\
\text { assessment }\end{array}$ \\
\hline $\begin{array}{l}\text { - Asses the results of } \\
\text { observations }\end{array}$ & $\begin{array}{l}\text { - State results } \\
\text { - Justify procedures } \\
\text { - Present arguments }\end{array}$ & $\begin{array}{l}\text { - Identifying assumptions } \\
\text { and reasons that were not } \\
\text { stated }\end{array}$ & $\begin{array}{l}\text { - Communicate the } \\
\text { results }\end{array}$ \\
\hline $\begin{array}{l}\text { - Deduce and judge } \\
\text { deductions } \\
\text { - Deduce and judge } \\
\text { induction } \\
\text { - Conduct evaluation }\end{array}$ & $\begin{array}{l}\text { - Query evidence } \\
\text { - Conjecture alternative } \\
\text { - Draw logically valid or } \\
\text { justified coclusions }\end{array}$ & - Generalizing & - Make a conclusion \\
\hline
\end{tabular}

Table 5. Indicators of critical thinking skills that will be used in the study

\begin{tabular}{|c|l|l|}
\hline No. & \multicolumn{1}{|c|}{ Indicators } & \multicolumn{1}{c|}{ Description } \\
\hline 1 & Identify the problem & Identify reasons, focus and formulate questions and hypotheses. \\
\hline 2 & Categorizing & $\begin{array}{l}\text { Understand or sort the various situations, experiences, events, data, } \\
\text { assessments, criteria, procedures, forms of problems, and strategies. }\end{array}$ \\
\hline 3 & Conduct an assessment & $\begin{array}{l}\text { Apply principles or formulas, consider alternatives, select criteria for making } \\
\text { solutions, and formulate alternative solutions. }\end{array}$ \\
\hline 4 & Communicate the results & Prepare notes, reinforce evidence, and report the observations. \\
\hline 5 & Make a conclusion & $\begin{array}{l}\text { Looking for relevant and valid information, evaluating the information and } \\
\text { facts obtained, and making deductions and inductions. }\end{array}$ \\
\hline
\end{tabular}

Based on the description above, critical thinking skills are a sensible and reflective thought process to prove, interpret, solve problems, and make decisions. Critical thinking skills indicators include identifying the problem, categorizing, conduct an assessment, communicate the results, and make a conclusion.

\subsection{Technology Literacy}

In general, the technology is the way for humans to modify the natural world to suit their own purposes.
Technology literally means the act of making or crafting, however, it is more generally to the diverse collection of processes and knowledge that people use to expand human capabilities and to fulfill human needs and desires [43]. Technology is the application of knowledge for the practical purposes of human life or to change and manipulate the human environment. Technology contains the use of materials, tools, techniques, and resources to make life easier or more enjoyable and work more productive [44]. 
Technology literacy is the main achievement of technology and engineering intensive education [45]. Technological literacy is the ability to use, manage, assess, and understand technology. Technological literacy is important for all students, because technology is a very important force in our economy, anyone can benefit from knowing it. Corporate executives, investment analysts, journalists, teachers, doctors, nurses, farmers and housewives would all be able to do their jobs better if they were technology literacy. In the individual level, technology literacy helps the consumers better value products and make smarter purchasing decisions while at the community level, technology literacy assists people make better decisions as well [43].
The components of technology literacy include knowledge, capacity or ability, critical thinking and the making of decisions. The dimension of technological literacy that is very important is the ability/capacity, which focuses on the ability to do; for example, specific technological processes/procedures by integrating various activities and skills [45]. The standards for technology literacy are designed as a guide to educate the students in developing technology literacy [43]. The synthesis of technology literacy's indicators can be seen in Table 6 and indicators of technology literacy that will be used in the study can be seen in Table 7 below.

Table 6. Synthesis of technology literacy's indicators

\begin{tabular}{|c|c|c|c|}
\hline ITEA, 2007 [43] & CTTE, 2009 [46] & NAGB, 2013 [47] & Synthesis \\
\hline The nature of technology & The nature of technology & & $\begin{array}{l}\text { The nature of } \\
\text { technology }\end{array}$ \\
\hline Technology and society & Technology and society & Technology and society & $\begin{array}{l}\text { Technology and } \\
\text { society }\end{array}$ \\
\hline Design & Design & Design and systems & \\
\hline $\begin{array}{l}\text { Abilities for a technological } \\
\text { world }\end{array}$ & $\begin{array}{l}\text { Abilities for a technological } \\
\text { world }\end{array}$ & & $\begin{array}{l}\text { Abilities for a } \\
\text { technological world }\end{array}$ \\
\hline The designed world & The designed world & $\begin{array}{l}\text { Information and } \\
\text { communication technology } \\
\text { (ICT) }\end{array}$ & The designed world \\
\hline
\end{tabular}

Table 7. Indicators of technology literacy

\begin{tabular}{|c|l|l|}
\hline No. & \multicolumn{1}{|c|}{ Indicators } & \multicolumn{1}{|c|}{ Description } \\
\hline 1 & The Nature of Technology & $\begin{array}{l}\text { Describe the characteristics and scope of technology, link the } \\
\text { technology and science, identify the positive and negative impacts of } \\
\text { using technology. }\end{array}$ \\
\hline 2 & Technology and Society & $\begin{array}{l}\text { Identifying of the relationship between technology and society, } \\
\text { assessing the role of society in the development and use of technology, } \\
\text { assessing the importance of technology innovation, demonstrating of } \\
\text { the appropriate and inappropriate use of technology in society, } \\
\text { making informed decisions about the effects of technology use. }\end{array}$ \\
\hline 3 & Abilities for a Technological World & $\begin{array}{l}\text { Identify the main components of how technology products work and } \\
\text { how to manufacture them, operate and maintain technology products } \\
\text { and systems, assess the strengths and weaknesses of technology } \\
\text { products, formulate solutions to problems related to technology } \\
\text { products. }\end{array}$ \\
\hline 4 & The Designed World & $\begin{array}{l}\text { Analyze of the principles, concepts, and applications of energy and } \\
\text { power technology as part of the artificial world. }\end{array}$ \\
\hline
\end{tabular}


Based on the description above, technology literacy is an important achievement of technology and engineering in the form of the ability to use, manage, assess, and understand technology. Technology literacy indicators include the nature of technology, technology and society, capabilities in the technological world, and the artificial world.

\subsection{Development of STS IPA Learning Tools Integrated Local Potential of Kacang Shanghai to Increase Critical Thinking Skills and Technology Literacy}

The STS IPA learning device integrated with the local potential of kacang shanghai is a learning tool using the STS approach and each learning step is integrated with the process of making kacang shanghai. The learning media facilitate the students to develop critical thinking skills and technology literacy. Habitual critical thinking skills can be built from the learning in the classroom [48]. It can be trained to the students through learning [49] while increasing students' curiosity so that students seek information and formulate solutions to the facing of problems [50]. Teachers need to adjust appropriate learning in order to develop students' critical thinking skills [10].

The STS IPA learning media integrated with the local potential of kacang shanghai connects three aspects of STS, i.e., science, technology, and society. Firstly, science is contained in the concepts and principles of temperature and heat materials related to the process of making kacang shanghai. Secondly, technology is found in the tools used in the process of making kacang shanghai. Thirdly, society is in the conditions of the people who work in the kacang shanghai company. The three aspects are interrelated and included in the learning steps carried out. The application of this learning tool is expected to hone students 'skills in analyzing problems related to the process of making kacang shanghai (that exist in students' daily lives), formulating problem solutions, analyzing the use of technology in making kacang shanghai, and assessing the advantages and disadvantages use of these technologies. The relationship between the integrated STS IPA learning tools local potential of kacang shanghai, critical thinking skills, and technology literacy can be shown in Table 8 below.

Table 8. The relationship between STS IPA learning tools integrated local potential of kacang shanghai, critical thinking skills, and technology literacy

\begin{tabular}{|l|l|l|}
\hline $\begin{array}{c}\text { STS IPA Learning Tools Integrated Local } \\
\text { Potential of Kacang Shanghai }\end{array}$ & \multicolumn{1}{|c|}{ Critical Thinking Skills } & \multicolumn{1}{|c|}{ Technology Literacy } \\
\hline Invitation & Identify the problem & - \\
\hline Exploration & Categorizing & $\begin{array}{l}\text { The nature of technology, } \\
\text { technology and society, abilities } \\
\text { for a technological world, the } \\
\text { designed world. }\end{array}$ \\
\hline Explanations and Solutions & $\begin{array}{l}\text { Conduct an assessment, communicate } \\
\text { the results }\end{array}$ & $\begin{array}{l}\text { Abilities for a technological } \\
\text { world }\end{array}$ \\
\hline Determination of action & Make a conclusion & Technology and society \\
\hline
\end{tabular}

The invitation step facilitates students to identify problems, namely by formulating questions and formulating hypotheses. The exploration step facilitates students to categorize, namely by looking for information that is relevant to the problems encountered. The exploration step also facilitates students to understand the nature of technology, the relationship between technology and society, skills in the use of technology, and to know the concepts and principles of science in technology. The explanations and solutions steps facilitate students to make assessments and state the results, namely by presenting the results of the experiments/ information searches carried out. The explanations and solutions steps also facilitate students to know the concepts and principles of science in technology. The detremination of action steps facilitate students to make a conclusion 
and know the relationship between technology and society.

\section{CONCLUSION}

The integrated STS IPA learning media by local potential of kacang shanghai is able to improve critical thinking skills and technology literacy. The learning steps in this learning device facilitate the students to develop critical thinking skills and technology literacy. Linking of three aspects of STS helps the students to analyze several problems that occur in everyday life related to technology and science concepts.

\section{REFERENCES}

[1] D. I. Perdana, Kurikulum dan Pendidikan di Indonesia: Proses Mencari Arah Pendidikan yang Ideal di Indonesia atau Hegemoni Kepentingan Penguasa Semata?, Jurnal Pemikiran Sosiologi 2 (2013) 63-74. DOI: https://doi.org/10.22146/jps.v2i1.23412

[2] N. M. Arumisore, S. Indana, and Soetjipto, Pengembangan Perangkat Pembelajaran IPA Berbasis Pendekatan Saintifik untuk Menuntaskan Hasil Belajar Siswa Pokok Bahasan Sistem Gerak Manusia di SMP, Jurnal Penelitian Pendidikan Sains 7(1) (2017) 386396.

DOI: https://doi.org/10.26740/jpps.v7n1.p1386-1396

[3] S. E. Atmojo, Pengembangan Perangkat Pembelajaran IPA Terpadu Berpendekatan Etnosains, Jurnal Pendidikan Sains 6(1) (2017) 5-13.

DOI: https://doi.org/10.26714/jps.6.1.2018.5-13

[4] G. Rahayuni, Hubungan Keterampilan Berpikir Kritis dan Literasi Sains pada Pembelajaran IPA Terpadu dengan Model PBM dan STM, Jurnal Penelitian dan Pembelajaran IPA 2(2) (2016) 131-146.

DOI: https://doi.org/10.30870/jppi.v2i2.926

[5] A. Fisher, Critical Thinking: An Introduction, Cambridge University Press, 2001.

[6] R. Septikasari and R. N. Frasandy, Keterampilan 4C Abad 21 dalam Pembelajaran Pendidikan Dasar, Jurnal Tarbiyah Al-Awlad 8(2) (2018) 107-117.

[7] F. Ibda, Perkembangan Kognitif: Teori Jean Piaget, Jurnal Intelektualita 3(1) (2015) 27-38.

[8] NCES, TIMSS 2011 Results, NCES, 2011.

[9] NCES, PISA 2018 Results, NCES, 2018.
[10] W. M. Nisa, Z. Nafiah, and I. Wilujeng, Profile of critical thinking skills in student's SMPN 1 kalipare at topic of substance and its characteristics, in: Proceedings of the $5^{\text {th }}$ International Seminar on Science Education (ISSE), IOP Publishing, 2020, pp. 1-4. DOI: https://doi.org/10.1088/17426596/1440/1/012081

[11] Y. Anjarsari, Profil Keterampilan Berpikir Kritis Siswa Kelas VII SMP Negeri 16 Bintan pada Materi Pencemaran Lingkungan, Artikel eJournal (2019) 1-13.

[12] A. Anisa, Meningkatkan Keterampilan Berpikir Kritis Peserta Didik Melalui Pembelajaran IPA Berbasis Potensi Lokal Jepara, Jurnal Inovasi Pendidikan IPA 3(1) (2017) 1-11. DOI: https://doi.org/10.21831/jipi.v3i1.8607

[13] Hunaepi, Pengembangan Perangkat Pembelajaran Sains SMP Berorientasi pada Pendekatan Sains Teknologi Masyarakat untuk Meningkatkan Kemampuan Kognitif, Jurnal Prisma Sains 1(1) (2013) 23-36. DOI: https://doi.org/10.33394/j-ps.v1i1.516

[14] M. A. Rose, Perceptions of Technological Literacy among Science, Technology, Engineering, and Mathematics Leaders, Jurnal Technology Education 19(1) (2007) 35-52.

[15] S. Rahayu, Sugiyarto, W. Sunarno, Pembelajaran IPA melalui Pendekatan Kontekstual Menggunakan Simulasi Komputer dan Model Kerja Ditinjau dari Kemampuan Berpikir Kritis dan Gaya Belajar, Jurnal Inkuiri 2(3) (2013) 279_ 287.

DOI:

https://doi.org/10.20961/inkuiri.v2i03.9802

[16] I. P. M. Dewi, I. G. P. Suryadarma, I. Wilujeng, and S. Wahyuningsih, The Effect of Science Learning Integrated with Local Potential of Wood Carving and Pottery Towards The Junior High School Students' Critical Thinking Skills, Jurnal Pendidikan IPA Indonesia 6(1) (2017) 103-109.

DOI: https://doi.org/10.15294/jpii.v6i1.9598

[17] A. Khoiri, Local Wisdom for Early Childhood Education as an Instrument to Enhance Student's Soft Skill (Study Cash: Development RKH on Science Learning), Indonesian Journal of Early Childhood Education Studies 5(1) (2016) pp. 1417.

DOI: https://doi.org/10.15294/ijeces.v5i1.11271

[18] P. U. W. Agustin, S. Wahyuni, R. W. Bachtiar, Pengembangan Modul Fisika Berbasis Potensi Lokal 'Batik Lumbung dan Tahu Tamanan' untuk Siswa SMA di Kecamatan Tamanan 
Bondowoso (Materi Suhu dan Kalor), Jurnal Pembelajaran Fisika 7(1) (2018) 62-69. DOI: https://doi.org/10.19184/jpf.v7i1.7226

[19] S. Chodijah, A. Fauzi, R. Wulan, Pengembangan Perangkat Pembelajaran Fisika Menggunakan Model Guided Inquiry yang Dilengkapi Penilaian Portofolio pada Materi Gerak Melingkar, Jurnal Penelitian Pembelajaran Fisika 1(1) (2012) 1-19. DOI: https://doi.org/10.1234/jppf.v1i1.603

[20] A. A. P. Saifiana, T. Purnomo, Pengembangan Perangkat Pembelajaran IPA Model Project Based Learning (PjBL) untuk Meningkatkan Hasil Belajar Siswa Kelas VII SMPN 2 Sidorajo, PENSA E-Jurnal: Pendidikan Sains 5(2) (2017) pp. 92-98.

[21] I. Akhlis and N. R. Dewi, Pengembangan Perangkat Pembelajaran Science Berorientasi Cultural Deviance Solution Berbasis Inkuiri Menggunakan ICT untuk Mengembangkan Karakter Peserta Didik, Jurnal Pendidikan IPA Indonesia 3(1) (2014) 86-94. DOI: https://doi.org/10.15294/ipii.v3i1.2905

[22] Baharuddin, Pengembangan Perangkat Pembelajaran IPA Berbasis Inkuiri Terbimbing dengan Tugas Proyek Materi Sistem Ekskresi untuk Menuntaskan Hasil Belajar Siswa SMP, Jurnal Biology Science \& Education 5(1) (2016) $1-10$.

DOI: https://doi.org/10.24815/jipi.v1i1.9574

[23] Hairunisa and A. R. Hakim, Pengembangan Perangkat Pembelajaran IPA Model Inkuiri Terbimbing Berbasis Multiple Intelligences untuk Melatihkan Keterampilan Proses Sains Peserta Didik SMP, Jurnal Pendidikan MIPA 8(1) (2018) 52-59. DOI: https://doi.org/10.37630/jpm.v8i1.58

[24] P. F. Oliva, Developing The Curriculum Third Edition, Harper Collins, 1991.

[25] R. I. Sari and S. S. Wulandari, Pengembangan Lembar Kegiatan Peserta Didik (LKPD) Berbasis Pendekatan Saintifik Mata Pelajaran Humas dan Keprotokolan Semester Gasal Kelas XI OTKP di SMK YPM 3 Taman, Jurnal Pendidikan Administrasi Perkantoran 8(3) (2020) 440-448.

[26] H. Akcay and R. E. Yager, The Impact of a Science / Technology / Society Teaching Approach on Student Learning in Five Domains, Journal of Science Education and Technology 19(6) (2010) 602-611. DOI: https://doi.org/10.1007/s10956-010-9226-7

[27] D. Marwah, D. Wahyudin, R. Cynthia, Efektivitas Penerapan Model Pembelajaran
Science Technology and Society (STS) terhadap Peningkatan Kemampuan Berpikir Tingkat Tinggi, Jurnal Edutechnologia 1(2) (2017) 171182.

[28] S. Gathong and S. Chamrat, The Implementati on of Science, Technology and Society Environment (STSE)-based Learning for Developing PreService General Science Teachers' Understanding of the Nature of Science by Empirical Evidence, Jurnal Pendidikan IPA Indonesia 8(3) (2019) 354-360. DOI: https://doi.org/10.15294/jpii.v8i3.19442

[29] D. Kauchak and P. Eggen, Strategie and Models for Teacher: Teaching Content and Thinking Skill, Pearson Education Inc, 2012.

[30] A. Poedjiaji, Sains Teknologi Masyarakat: Model Pembelajaran Kontekstual Bermuatan Nilai, Remaja Rosdakarya, 2010.

[31] Zuldafrial, Strategi Belajar Mengajar, Cakrawala Media, 2012.

[32] Hunaepi, T. Samsuri, M. Asy'ari, and R. Sukaisih, Sains Teknologi Masyarakat: Strategi, Pendekatan, dan Model Pembelajaran, Duta Pustaka Ilmu, 2014.

[33] I. Wilujeng, Z. K. Prasetyo, and I. G. P. Suryadarma, Science learning based on local potential: overview of the nature of science (nos) achieved, in: Proceedings of the $4^{\text {th }}$ International Conference on Research, Implementation, and Education of Mathematics and Science (4th ICRIEMS), vol. 80005, IOP Publishing, Bristol, 2017, pp. 1-7. DOI: https://doi.org/10.1063/1.4995189

[34] A. Khoiri, A. Syifa, and N. Mubin, Potential Local Physics Based Learning of Jepara District to Improve Science Process Skills and Students Entrepreneurship, Formatif: Jurnal Ilmiah Pendidikan MIPA 8(1) (2018) pp. 57-68. DOI: https://doi.org/10.30998/formatif.v8i1.2365

[35] Situmorang, Analisis Potensi Lokal untuk Mengembangkan Bahan Ajar Biologi di SMA Negeri 2 Wonosari, Jurnal Pendidikan Sains 4(1) (2016) 51-57. DOI: https://doi.org/10.26714/jps.4.1.2016.51-57

[36] I. Wilujeng, Z. K. Prasetyo, and I. G. P. Suryadarma, Integrating local wisdom in natural science learning, in: Proceeding of the $1^{\text {st }}$ Internasional Conference on Innovation in Education, vol. 178, Atlantis Press, France, 2018, pp. 182-186. DOI: https://doi.org/10.2991/icoie18.2019 .42

[37] A. M. Santoso, Konsep Diri melalui Pendidikan 
Berbasis Keunggulan Lokal sebagai Model Pendidikan Berkarakter dan Berbudaya Bangsa di Era Global, in: Proceedings of the $4^{\text {th }}$ International Conference on Teacher Education; Join Conference, UPI \& UPSI, 2010, pp. 477486.

[38] R. H. Ennis, A Logical Basis for Measuring Critical Thinking Skills, Association for Supervision and Curriculum Development, 1985.

[39] R. H. Ennis, The Nature of Critical Thinking: An Outline of Critical Thinking Dispositions and Abilities, 2011, pp. 1-8.

[40] P. A. Facione, Critical Thinking: What It Is and Why It Counts. 2015.

[41] Nurkholifah and T. Mayasari, Profil Kemampuan Berpikir Kritis Pelajaran Fisika Siswa SMP, in: Proceedings of the Seminar Nasional Quantum, vol. 25, 2018, pp. 569-574.

[42] M. Tawil and Liliasari, Berpikir Kompleks dan Implementasi dalam Pembelajaran IPA, Badan Penerbit UNM, 2013.

[43] ITEA, Standards for Technological Literacy: Content for The Study of Technology (3rd Ed.), Internasional Technology Education Association, 2007.

[44] M. Barak, Teaching Engineering and Technology: Cognitive, Knowledge and Problem-Solving Taxonomies 11 (2018) pp. 316-333. DOI: https://doi.org/10.1108/JEDT-042012-0020
[45] S. Avsec and J. Jams, Technological Literacy for Students Aged 6-18: A New Method for Holistic Measuring of Knowledge, Capabilities, Critical Thinking and Decision-Making, International Journal of Technology and Design Education 26 (2016) 43-60. DOI: https://doi.org/10.1007/s10798-015-9299-y

[46] CTTE, Essential Topics for Technology Educators, The McGraw-Hill Companies, Inc., 2009.

[47] NAGB, Technology and Engineering Literacy Framework for The 2014 National Assesment of Educational Progress, National Assesment Governing Board, 2013.

[48] A. T. Kartika, L. Eftiwin, M. F. Lubis, and A. Walid, Profil Kemampuan Berpikir Kritis Siswa Kelas VIII SMP pada Mata Pelajaran IPA, Jurnal Riset Teknologi dan Inovasi Pendidikan 3(1) (2020) 1-10. DOI: https://doi.org/10.36765/jartika.v3i1.46

[49] S. Ridho, Ruwiyatun, B. Subali, and P. Marwoto, Analisis Kemampuan Berpikir Kritis Siswa Pokok Bahasan Klasifikasi Materi dan Perubahannya, Jurnal Penelitian Pendidikan IPA, 6(1) (2020) 10-15. DOI: https://doi.org/10.29303/jppipa.v6i1.194

[50] H. Saputra, A. Hidayat, and Munzil, Profil kemampuan berpikir kritis siswa smpn 7 pasuruan, in: Proceedings of the Seminar Pendidikan IPA, Pascasarjana UM, 2016, pp. 943-949. 